\title{
Teachers' Perceptions of Interactive Boards for Teaching and Learning in Public and Private High Schools in the Arab Education System in Israel
}

\author{
http://dx.doi.org/10.3991/ijet.v7i1.1775 \\ W. Daher ${ }^{1,2}$, J. Abu-Hussein ${ }^{1}$ and E. Alfahel ${ }^{1,3}$ \\ ${ }^{1}$ Al-Qasemi Academic College of Education, Baka, Israel \\ 2 An-Najah National University, Nablus, Palestine \\ ${ }^{3}$ Kaye Academic College of Education, Beer-Sheva, Israel
}

\begin{abstract}
Interactive boards are becoming an integral part of the educational scene in schools in the western countries and are not considered just an additional aid to teaching. In Israel too, interactive boards are becoming gradually part of the educational scene, so evaluation is needed for various aspects of teachers' teaching and students' learning with these new tools. One such important aspect is teachers' perceptions of the interactive board as a tool for teaching and learning. This research intended to examine the difference between teachers' perceptions of four aspects of the interactive boards: pedagogic, didactic, technical-pedagogic, and technical-didactic aspects. We examined teachers' perceptions of these aspects in public and private schools. In addition, we examined the difference between the perceptions of those who use the computer for teaching and those who do not. Further, we examined the reasons that prevent teachers from using the interactive boards in public schools as compared to private schools.
\end{abstract}

The data was collected through a questionnaire which examines teachers' perceptions of four aspects of using the interactive boards. The participants were 217 high school teachers (157 public high school teachers and 60 private high school teachers). The research findings show that there exist significant differences between teachers' perceptions of the interactive board for teaching and learning regarding (1) type of school, and (2) use of computers for teaching goals. No significant difference was found between reasons that prevent teachers from using the interactive boards in public and private school except one reason: the shortage of interactive board in every classroom. We discuss the findings and draw appropriate conclusions. It was also interesting to examine the reasons that prevent teachers from using the interactive boards, and whether there is difference in these reasons in public schools as compared to private schools.

Index Terms-Interactive boards, teachers' perceptions, public schools, private schools.

\section{INTRODUCTION}

According to the Promethean site, an interactive whiteboard is a large interactive display that combines a whiteboard, a computer and front projection. As learning tools they engage students with vivid images, video and audio. Further, they enable anything that can be done on a computer screen to be projected onto an interactive whiteboard. According to Smart Technologies site, the first interactive board was introduced by Smart Technologies in 1991. Since then, they are becoming an integral part of the educational scene in schools in the western countries and are not considered just an additional aid to teaching teaching ([1], [2]). This also has been the case for the last couple of years in the Arab schools in Israel, so evaluation is needs for the teaching and learning going on with the interactive boards. One aspect of this learning is the teachers' perception of the interactive boards as tools for teaching and learning. This research will attempt, using quantitative methods, to examine such perceptions regarding didactic and pedagogic issues. It will examine whether there are differences between (1) teachers in public schools vs. teachers in private schools; and (2) teachers who use computers in their teaching vs. teachers who do not. Further the research will examine teachers' reasons for not using the interactive boards in their teaching and whether there are differences in these reasons between teachers in public schools vs. teachers in private schools.

\section{LITERATURE REVIEW}

\section{A. Educational Uses of Interactive boards}

Researchers point that interactive boards help change, improve or add to the teaching methods of teachers who use them in the classroom ([3], [4], [5] \& [6]. Ref. [3], for example, administered a questionnaire in internet sites about teachers' opinions regarding the use of interactive boards in learning in elementary and middle schools. The findings show that when the interactive boards are installed in the classrooms and when the teachers have the required skills for using those interactive boards, a technological environment will be created which will support teachers and enable the transformation of their teaching methods to ones that are appropriated for the diverse population of their students.

Interactive boards add more resources and strategies to the teaching methods of teachers, enabling them to use more efficiently learning resources ([7], [3], [8], [5]). At the same time, they help teachers provide the students with more challenging learning opportunities ([4]). Ref. [5], for example, found that teachers looked at the interactive boards as aiding in presenting information and learning resources (as the easiness with which it is possible to draw on a greater number and wider variety of information and learning resources), in facilitating classroom interaction and activity (as freeing up time for interaction 
and task-related activity), and in their educational impact (as helping teachers to give more effective explanations).

Interactive boards not only contribute to the teacher but to the student too, supporting his learning - enabling understanding, concentrating, presenting information, remembering, thinking processes, and playing, and causing motivation ([9]; [5]; [10]; [11]); stimulating learning through increasing motivation, fun, self confidence, attention, and interest ([12]; [11]); providing preferred learning approaches - through supporting different learning styles: visual, audio, verbal-social, and kinesthetic ([10], [11]); making students involved more interactively in learning and more focused on the learning material ([4]; [5]; enabling connectedness in an easy way - with the software, the hardware, and the multimedia ([11]); enabling wide range of learning resources and materials ([3]; [10]) and increasing the student's achievement ([9]; [13]).

The previous researches described the advantages of using interactive boards in the classroom, while other researches reported that interactive boards had no significant impact on the educational scene in schools. For example, Ref. [14] reviewed some educational studies in the world which reported that no significant change in the class discussions occurred, nor in the basic pedagogy of teaching, but a consistent change did happen in the approach and teaching method of teachers who used the interactive boards. Further, installing an interactive board in the classrooms and supplying laptops to all teachers promote the implementation of computerized learning environments. It can be concluded from the previous researches that a successful use of the interactive board improves the learning and teaching processes in the following aspects: the didactic, the pedagogic, the technicalpedagogic and the technical-didactic.

\section{B. Pedagogy and didactics}

Two educational aspects which this research is concerned with are pedagogy and didactics. Ref. [15] differentiates between them saying that pedagogy is concerned with the curriculum in both broad and narrow forms, and the underlying systemic aims and objectives of education. In addition, pedagogy transcends subject boundaries and acknowledges general theories of teaching and learning. For [15], pedagogy includes didactics, which is concerned with the strategies and warranted approaches to subject teaching and learning. These strategies and approaches may vary from one subject to another. In addition, didactics acknowledge theories of teaching and learning but from the subject-specific perspective. Ref. [16] described the pedagogic knowledge as the knowledge of pedagogic principles and techniques that are concerned with efficient teaching, and which is not concerned with a specific subject. Ref. [16] described the pedagogic content knowledge as the knowledge concerned with the teaching methods of a specific subject. In the current research we will treat the pedagogy and didactics aspects of the interactive boards in the terms of Ref. [16], where the didactic aspect is the pedagogic content knowledge according to Shulman. The two aspects of teachers' knowledge were attended to by researchers, for example Ref. [17] and Ref. [18] point at the content pedagogic knowledge as a critical component of teaching and learning. Regarding the pedagogic knowledge, Ref. [19] who examined the pedagogic knowledge of university instructors in Brazil says that beyond the content knowledge in which instructors are experts, they should have the abilities and skills as nurturing student-instructor relationships, encouraging student's creativity and his critical thinking, and encouraging students' abilities to ask questions and their will to discover and invent. Ref. [20] includes the following components in mathematical pedagogic content knowledge: the connections used by the teacher between different mathematical subjects or different mathematical topics, the methods used by the teacher to represent a specific mathematical topic or concept, and the knowledge of students' errors in a specific mathematical topic or concept.

Regarding the pedagogic knowledge, Ref. [19] who studied the pedagogic knowledge of university professors pointed that not only content knowledge is needed for those professors, but pedagogic knowledge too, for pedagogic knowledge enables to cultivate different aspects of the university professors' teaching, for example building positive relationship with students, stimulating the creativity of the professors, encouraging their critical thinking, and developing their ability to ask questions and invent new ideas.

The current research takes care of two other aspects of teachers' knowledge: the technical-pedagogic aspect and the technical-didactic aspect. The technical-pedagogic aspect is related to issues which result from the reciprocity between the technical aspect of the interactive board and the pedagogic aspect, for example the extent to which the board enables the teacher to present information from the internet during the lesson. The technical-didactic aspect is related to issues which result from the reciprocity between the technical aspect of the interactive board and the didactic aspect, for example the extent to which the interactive board provides the teacher with technological options for teaching specific subject. A specific example on this aspect is that the interactive board provides the mathematics teacher with a set of geometric figures, so he can draw accurately the figures he needs while teaching specific mathematical topics. The availability of those figures (an issue related to the technical aspect of the interactive board) could influence the accuracy and frequency of drawing geometric figures (an issue related to the didactic aspect of the teacher's work).

An educational aspect which has a reciprocal relationship with the aspects described above is the teacher's perception of the interactive boards for teaching and learning.

\section{Perceptions of teachers}

Teachers' perceptions are an important element which influences the teacher's teaching method and his behavior in the classroom. This makes teachers' perceptions an element which influences students' learning as well. Researches show the impact of teachers' perceptions, expectations and opinions on their behavior in the classroom and on their students' learning. Ref. [20] say that teachers' perceptions influence the success or failure of integrating computer games into the classrooms. Ref. [21], in a research which included 173 students and 7 teachers, reports that students' achievement validates their teacher's expectations from them. Several researchers treated the influence of perceptions on the behavior, saying that one's perceptions of the self and the reality in which he lives influence his behavior, where perceptions are not passive process of absorption of facts and impressions, but a compound and active process which is influenced from 
various variables - as past experiences, expectations and emotions - which design our perception's domain ([22]). The mentioned importance of the perceptions makes it necessary to examine teachers' perception of working with interactive boards, so to evaluate the possible behaviors which could results from them.

\section{RESEARCh RATIONALE, GoAls AND HypotheSES}

\section{A. Research rationale and goals}

The interactive boards are becoming an integral part of the educational scene in Arab schools in Israel, where money and time are spent to utilize these new electronic tools in the classroom. We intended to examine the results of the introduction of interactive boards in the classroom on teachers' perceptions of their pedagogic, didactic, technical-pedagogic and technical-didactic aspects. The examining of these perceptions will shed light on the teachers' practices with the interactive boards for teaching and learning and enables better evaluation how to proceed with the use of interactive boards in the classroom, further, little research has been done on teachers' perceptions of the four studied aspects of the electronic board, on the difference of these perceptions in different types of schools (private, public), or on the relation of these perceptions and the previous experience of teachers with using computers for teaching goals.

\section{B. Research hypotheses}

Number equations consecutively with equation numbers in parentheses flush with the right margin,

1. There exists a significant difference in teachers' perceptions of interactive boards for teaching and learning between teachers in private and public schools.

2. There exists a significant difference in teachers' perceptions of interactive boards for teaching and learning between teachers who use the computer in teaching and those who do not.

3. There is significant difference in the reasons that prevent teachers from using the interactive boards between teachers in private and public schools.

The first and third hypotheses presume that private and public schools differ in their organizational culture and the expectations of the school administration from teachers. This difference in the organizational culture would result in difference in teachers' perceptions of their work, here their perceptions of the interactive board for teaching and learning. It also would result in differences regarding teachers' work in the schools, here the reasons that prevent them from using the interactive boards in the classrooms. This is supported in the literature, for example Ref. [24] found that higher levels of efficacy of teachers in Catholic private schools than in public schools can be explained by organizational differences.

The second hypothesis presumes the influence that experience and knowledge have over one's behavior and perception. Ref. [25] found that teachers' experience with video games influenced their perceptions of games as educational tools. Further, Ref. [26] found that past experience influenced positively teachers' perceptions, and thus causes them to have effective teaching practicum. Specifically, Ref. [27] found that as computer experience increases, self-efficacy also increases while computer anxiety decreases. We expect that experience with the computer not only decreases computer anxiety but also anxiety related to other technological tools, and specifically influence positively teachers' perceptions of the interactive board.

\section{MethodOLOGY}

\section{A. Research setting and participants}

The research examines teachers' perceptions of the interactive boards in two types of schools: public schools and private schools. In the Arab sector in Israel more than eighty percent of the schools are public schools, but this ratio decreases to two thirds when coming to the high schools.

Two hundred seventeen high school teachers from Haifa district participated in the research. These were divided to 157 teachers from public schools and 60 teachers from private schools.

\section{B. Research Design}

The research design is a comparative descriptive one, where we compare between different groups of teachers (public school teachers vs. private school teachers, teachers who use the computer in their teaching vs. teachers who do not) regarding their perception of the interactive board for teaching and learning.

The schools were chosen randomly, where the necessary condition for choosing a school to participate in the research was that part of its teachers participated in a workshop for using the interactive board or that there are interactive boards in the school. This condition tried to guarantee that the teachers participating in the research had already been exposed to the interactive boards.

\section{The research tool}

A questionnaire was constructed to examine teachers' perceptions of the interactive boards for teaching and learning in the classroom. This questionnaire examines four educational aspects: the pedagogic (16 items), the didactic (11 items), the technological-pedagogic (6 items) and the technological-didactic (3 items) aspects.

The questionnaire is composed of two parts (see appendix 1). The first part is concerned with the teacher's personal information (gender, participation in a workshop that treated the interactive board and the teacher's experience with the interactive board in the classroom). The first part is also concerned with information about the school (the school type and the school stage). The second part of the questionnaire includes 36 items which are concerned with the perceptions of teachers of interactive boards for teaching and learning regarding the various aspects: the pedagogic, the didactic, the technological-pedagogic and the technological-didactic aspects.

The teachers' perception of the pedagogic aspect is tested with the items: 1-16

The teachers' perception of the didactic aspect is tested with the items: 17-27

The teachers' perception of the technical-pedagogic aspect is tested with the items: 28-33

The teachers' perception of the technical-didactic aspect is tested with the items: 34-36

The participants were required to indicate the extent of their agreement on each item, where they were able circle 
one of the following possibilities: 1. I strongly disagree, 2. I disagree, 3. I agree, 4. I strongly agree.

There were eight reversed items: 2, 3, 11, 13, 18, 27, 30,36

The questionnaire underwent reliability and validity tests. The reliability test (Chronbach's alpha) for the whole questionnaire was computed and found to be $\alpha=0.897$. Table 1 shows the values of Chronbach's alpha for each of the four dimensions of the questionnaire.

Regarding the questionnaire validity, one of the authors constructed a questionnaire which includes 30 items. He handled it to the other two authors to give their remarks on it. They examined if it actually examines what it is supposed to examine and if the important aspects are covered. The two authors suggested changes in the statement of some items, so to make them clearer. They suggested removing items that repeat existing items or do not have relations with an aspect that it came to represent. At the same time they suggesting adding items which cover some sides of the aspect not covered by any of its items. At the next stage, the questionnaire was sent to three judges who have experience in interactive boards and in the four educational aspects. This time the suggested changes were minor and were about small changes in the statement of the items.

\section{Questionnaire distribution and data processing}

The teachers' perception of the technical-didactic aspect is tested with the items:

The SPSS 17 package was used for data processing. To test the research hypotheses we will compute averages, standard deviations and $\mathrm{t}$ and $\mathrm{F}$ tests for computing the significance level.

The questionnaire was distributed and collected from the teachers in September-October 2010.

\section{FINDINGS}

To examine the difference in high school teachers' perceptions of the interactive boards for teaching and learning between teachers in public schools and teachers in private schools we examined the means of those perceptions in four aspects - pedagogic, didactic, technical-pedagogic and technical-didactic for the two groups. We also ran the T-test to determine if the difference between the perceptions of the two groups is significant. Table 2 shows these computations.

The findings in Table 2 show that teachers in public high schools have positive perceptions of interactive boards for teaching and learning (with mean=3.03 and $\mathrm{SD}=0.42$ ), while teachers in private high schools have neutral perceptions of interactive boards for teaching and learning (with mean=2.62 and $\mathrm{SD}=0.15$ ). Further, the findings show that both groups of teachers have more positive perceptions of interactive boards in the technicaldidactic aspect than in the other aspects. In addition, there is significant difference between the two groups regarding their perception of the interactive board in the four aspects. These findings confirm the research first hypothesis; i.e. there is significant difference of the perception of interactive boards between teachers in public high schools and teachers in private high schools.

To examine the difference in teachers' perceptions of the interactive board for teaching and learning between
TABLE I.

CHRONBACH'S ALPHA FOR EACH OF THE FOUR DIMENSIONS OF THE QUESTIONNAIRE

\begin{tabular}{|l|c|}
\hline The dimension & Chronbach's alpha \\
\hline The didactic dimension & 0.823 \\
\hline The pedagogic dimension & 0.813 \\
\hline The technical- didactic dimension & 0.714 \\
\hline The technical- pedagogic dimension & 0.715 \\
\hline
\end{tabular}

TABLE II.

MEANS, STANDARD DEVIATIONS AND T VALUES FOR THE TEACHERS' PERCEPTIONS OF THE INTERACTIVE BOARD FOR TEACHING AND LEARNING IN PUBLIC AND PRIVATE HIGH SCHOOLS

\begin{tabular}{|l|l|l|l|l|l|}
\hline \multirow{2}{*}{ Aspect } & \multicolumn{2}{|c|}{$\begin{array}{c}\text { Teachers in } \\
\text { public high } \\
\text { schools } \\
\text { N=157 }\end{array}$} & \multicolumn{2}{c|}{$\begin{array}{c}\text { Teachers in } \\
\text { private high } \\
\text { schools } \\
\text { N=60 }\end{array}$} & \multirow{2}{*}{ t } \\
\cline { 2 - 5 } & Mean & \multicolumn{1}{|c|}{ SD } & Mean & \multicolumn{1}{|c|}{ SD } & \\
\hline Pedagogic & 3.05 & 0.45 & 2.60 & 0.26 & $* * 7.17$ \\
\hline Didactic & 2.94 & 0.46 & 2.65 & 0.30 & $* * 4.44$ \\
\hline $\begin{array}{l}\text { Technical- } \\
\text { pedagogic }\end{array}$ & 3.03 & 0.55 & 2.57 & 0.34 & $* * 5.86$ \\
\hline $\begin{array}{l}\text { Technical- } \\
\text { didactic }\end{array}$ & 3.23 & 0.65 & 2.81 & 0.53 & $* * 4.46$ \\
\hline General & 3.03 & 0.42 & 2.62 & 0.15 & $* * 7.14$ \\
\hline
\end{tabular}

TABLE III.

MEANS, STANDARD DEVIATIONS AND T VALUES FOR PERCEPTIONS OF THE INTERACTIVE BOARD OF TEACHERS WHO USE THE COMPUTER FOR TEACHING AND LEARNING AND TEACHERS WHO DO NOT IN PUBLIC AND PRIVATE SCHOOLS

\begin{tabular}{|c|c|c|c|c|c|c|}
\hline \multirow[t]{2}{*}{ Aspect } & \multirow{2}{*}{$\begin{array}{c}\text { Teacher's } \\
\text { use of the } \\
\text { computer } \\
\left(\begin{array}{c}\mathrm{N}=124) \\
\text { Yes } \\
(\mathrm{N}=93) \\
\text { No }\end{array}\right.\end{array}$} & \multicolumn{2}{|c|}{$\begin{array}{c}\text { Public high } \\
\text { schools } \\
\mathbf{N}=157\end{array}$} & \multicolumn{2}{|c|}{$\begin{array}{l}\text { Private high } \\
\text { schools } \\
\mathbf{N}=\mathbf{6 0}\end{array}$} & \multirow[t]{2}{*}{ t values } \\
\hline & & Mean & $S D$ & Mean & $S D$ & \\
\hline \multirow[t]{2}{*}{ Pedagogic } & Yes & 3.14 & 0.47 & 2.62 & 0.27 & $5.46^{* * *}$ \\
\hline & No & 2.90 & 0.38 & 2.58 & 0.26 & $4.21 * * *$ \\
\hline \multicolumn{2}{|c|}{ t values } & \multicolumn{2}{|l|}{$3.26 * *$} & \multicolumn{2}{|l|}{0.51} & \\
\hline \multirow[t]{2}{*}{ Didactic } & Yes & 3.04 & 0.48 & 2.67 & 0.29 & $3.78 * * *$ \\
\hline & No & 2.78 & 0.39 & 2.63 & 0.31 & 1.80 \\
\hline \multicolumn{2}{|c|}{ t values } & \multicolumn{2}{|l|}{$3.51 * *$} & \multicolumn{2}{|l|}{0.46} & \\
\hline \multirow{2}{*}{$\begin{array}{l}\text { Technical- } \\
\text { pedagogic }\end{array}$} & Yes & 3.14 & 0.54 & 2.56 & 0.28 & $5.26 * * *$ \\
\hline & No & 2.85 & 0.54 & 2.58 & 0.38 & $2.49 *$ \\
\hline \multicolumn{2}{|c|}{ t values } & \multicolumn{2}{|l|}{$3.22 * *$} & \multicolumn{2}{|l|}{0.20} & \\
\hline \multirow{2}{*}{$\begin{array}{l}\text { Technical- } \\
\text { didactic }\end{array}$} & Yes & 3.38 & 0.61 & 2.83 & 0.51 & $4.24 * * *$ \\
\hline & No & 2.98 & 0.64 & 2.78 & 0.55 & 1.46 \\
\hline \multicolumn{2}{|c|}{ t values } & \multicolumn{2}{|c|}{$3.94 * * *$} & \multicolumn{2}{|l|}{0.36} & \\
\hline \multirow[t]{2}{*}{ General } & Yes & 3.13 & 0.43 & 2.65 & 0.17 & $5.57 * * *$ \\
\hline & No & 2.86 & 0.34 & 2.61 & 0.13 & $4.09 * * *$ \\
\hline \multicolumn{2}{|c|}{ t values } & \multicolumn{2}{|c|}{$4.04 * * *$} & \multicolumn{2}{|l|}{1.00} & \\
\hline
\end{tabular}

teachers who use the computer for teaching and learning and teachers who do not we computed the means and standard deviations of teachers' perceptions of the interactive board in both groups. We also ran the T-test to determine if the difference between the perceptions of the two groups is significant. Table 3 shows these computations. 
The findings in Table 3 show that teachers who use the computer for teaching and learning have more positive perception of the interactive board for teaching and learning (with mean $=3.13$ and $\mathrm{SD}=0.43$ ) than teachers who do not use the computer for teaching and learning (with mean=2.86 and $\mathrm{SD}=0.34$ ). This is true also for the perceptions of teachers of every educational aspect of using the interactive boards for teaching and learning. No significant difference was found between the two groups in private high schools. These findings confirm the second research hypothesis regarding teachers in public high schools, while they reject the second research hypothesis regarding teachers in private high schools.

To examine the difference in the reasons which prevent teachers from using the interactive boards for teaching and learning between teachers in public high schools and teachers in private high schools we computed the percents of teachers who publicd the reason in the two types of schools. Table 4 shows these percents.

The findings in Table 4 show that the five reasons reported by the teachers to prevent them from using the interactive boards in the classrooms are reported by public school teachers as well as private school teachers. Further, no significant difference was found regarding four of the reported reasons between public and private schools teachers. The teachers of the two groups only had significant difference regarding the shortage of electronic boards in the classrooms, where this reason prevented private schools teachers from using the interactive boards for teaching and learning more than public school teachers. Thus the findings represented in Table 4 confirm only partially the third research hypothesis.

\section{DISCUSSION}

This research examined teachers' perceptions of the use of interactive boards for teaching and learning in high schools in the Arab educational system in Israel, where its goal was to find if there was a significant difference in the perception between public and private high school teachers. It was found that high school teachers in public schools have positive perception of the use of interactive boards in teaching and learning in the four educational aspects of their work. This positive perception could be related to the advantages that the high school teachers find in using the interactive boards for teaching and learning. One advantage could be that the use of interactive boards in the classroom improves students' achievement. This explanation fits what other researchers found regarding the relation of technological tools with students' achievement. Ref. [28], for example, reported that the use of computers in learning improved second grade students' achievement in mathematics, while Ref. [29] reported that eight grade students whose experience in using the computer was more than three years had original, fluent, flexible, and innovative thinking than students whose experience in using the computer is less than three years. Further, positive perceptions of the interactive board would have a positive impact on the utilization that teachers make of the interactive board potentialities. This utilization would enrich the teaching methods of the teachers and thus the learning of their students. The claim regarding the influence of teachers' perceptions on their behavior in the classroom is supported in the literature, for example Ref. [30] reported that teachers' beliefs influenced their daily pedagogic decisions, while Ref. [31]
TABLE IV.

THE DISTRIBUTION OF THE REASONS GIVEN BY PUBLIC AND PRIVATE HIGH SCHOOL TEACHERS FOR NOT USING THE INTERACTIVE BOARD FOR TEACHING AND LEARNING

\begin{tabular}{|l|c|c|c|}
\hline $\begin{array}{c}\text { Reasons that prevent } \\
\text { high school teachers } \\
\text { from using the interac- } \\
\text { tive board for teaching } \\
\text { and learning }\end{array}$ & $\begin{array}{c}\text { Teachers } \\
\text { in public } \\
\text { schools } \\
\mathbf{N = 1 0 9}\end{array}$ & $\begin{array}{c}\text { Teachers } \\
\text { in private } \\
\text { schools } \\
\mathbf{N}=32\end{array}$ & $\begin{array}{c}\text { Pearson } \\
\text { chi- } \\
\text { square }\end{array}$ \\
\hline $\begin{array}{l}\text { Lack of interactive boards } \\
\text { in the classrooms }\end{array}$ & $52.8 \%$ & $78.5 \%$ & $\begin{array}{c}12.47 \\
* * *\end{array}$ \\
\hline $\begin{array}{l}\text { Lack of skills to use the } \\
\text { interactive board for } \\
\text { teaching and learning }\end{array}$ & $69.2 \%$ & $75 \%$ & 0.40 \\
\hline $\begin{array}{l}\text { The regular board is more } \\
\text { effective than the interac- } \\
\text { tive board }\end{array}$ & $78 \%$ & $75 \%$ & 0.12 \\
\hline $\begin{array}{l}\text { Preparing lesson for the } \\
\text { regular board takes less } \\
\text { time than for the interac- } \\
\text { tive board }\end{array}$ & $88.1 \%$ & $75 \%$ & 3.33 \\
\hline $\begin{array}{l}\text { The working area in the } \\
\text { interactive board is less } \\
\text { than that in the interactive } \\
\text { board }\end{array}$ & $91.7 \%$ & $84.4 \%$ & 1.5 \\
\hline $\begin{array}{l}* * * \text { p }<0.001 \\
\text { nard }\end{array}$ & & & \\
\hline
\end{tabular}

reported that teachers' perceptions of geometry influenced their behavior in the classroom.

It is interesting that the highest mean of teachers' perception of the four educational aspects of working with the interactive board is that of the technical-didactic aspect. This indicates that teachers in both groups valued the contribution of the interactive board in this aspect because the interactive board helped them with teaching their specific subjects. This could be the case because of the various technological potentialities of the interactive board, for example the multimedia potentialities ([10]) which make teachers able to vary their methods in presenting learning topics, and this ability makes them value the contribution of the interactive board to the technological-didactic aspect of their work in the classroom.

The research findings show that there are significant differences between the perceptions of public high school teachers and private high school teachers of the use of interactive boards for teaching and learning in the four educational aspects, where the public high school teachers have more positive perception of the use of interactive boards in teaching and learning than the private high school teachers. Further, the perceptions' means of the private high school teachers of the interactive board are neutral in the four educational aspects (between 2.57 and 2.81). This neutral means can be due to the following reasons. First, the administration and the parents have higher expectations regarding the achievement of their students in private schools than in public schools (Ref. 32 ), so teachers in private schools are concerned more in covering the required learning material than in using new technological tools in their teaching. Second, students' achievement in private schools is higher than in public schools (Ref. 33; Ref. 34) and teachers are content with this achievement, so they do not look for new methods to improve their students' performance or achievement.

Regarding the second research question, it was found that public high school teachers who use the computer for 
teaching and learning have a more positive perception of the interactive board than public high school teachers who do not use the computer for teaching and learning. This significant difference in the perception of the interactive board is due to the fact that the computer and the interactive board are both technological tools, so experience with one of them could influence work with and perception of the other, for example experience with the computer would decrease the anxiety relation to using the computer and using information technology tools (Ref. 35). Further, experience with the computer is essential for an easy work with the interactive board (Ref. 36).

Regarding private high school teachers' perception of the interactive board for teaching and learning, no significant difference was found between teachers who use the computer for teaching and learning and teachers who do not. Further, the difference in the means of perceptions in the four educational aspects was small (from 0.04 to 0.08 , and overall 0.04). This small difference and the insignificant difference could be explained by both groups of teachers being occupied by their students' achievement, rather than trying new technological tools in their teaching. The common concerns of the teachers in both groups made the means of their perceptions of the interactive board similar.

Regarding the third research question, the findings show that most of the teachers (in the public as well as in the private schools) mentioned the five reasons as preventing them from using the interactive board for teaching and learning. The implementation of the interactive boards in Israel is still in its infancy and this explains the fact that most of the participating teachers mentioned every one of the five reasons as causing them not to use the interactive board for teaching and learning. Not only the implementation of the interactive boards is new but it seems also that the teachers have not participated in enough workshops that could have helped them to discover the potentialities of the interactive board. Ref. [37] reported that teachers who participated in a workshop about the interactive board recognized the necessity of attending training workshops. They also emphasized that knowing practical uses of interactive boards was helpful for them to integrate the new tool meaningfully into their teaching. So, diverse workshops are essential for making teachers aware of the potentialities and actual use of the interactive board in the classroom, and these diverse workshops are what new users of a technological tool, as our participants in the case of the interactive board, need in order to know in a practical way how to use the various technological options of the tool.

In the present research, there were no significant differences between four out of five reasons given by the public high school teachers and those given by the private high school teachers. The only reason for which there is significant difference between the two groups of teachers was the shortage of interactive boards in schools. The significance of this reason is due to the fact that the ministry of education provides the public schools with interactive boards as a policy to improve the existing educational system in public schools, whereas the private schools have to consider the costs and usefulness of the interactive boards before deciding to buy them. This makes administrations in the private schools hesitate regarding buying enough interactive boards for their teachers to use in the classrooms, because they are not sure yet of the benefits of the interactive boards or because the students' achievement in their schools are conceivable, so they do not see the need for buying enough interactive boards for the classrooms.

The insignificant differences between the teachers in the two groups regarding the other four reasons are due also to the novelty of the experience of the teachers in both groups in using the interactive boards for teaching and learning, for example, the teachers from both groups have not yet participated in enough workshops, so they do not consider themselves prepared for teaching with the interactive board. This explanation agrees with the argument of Ref. 38 reviews the literature to argue that lack of experience and as a consequence of confidence to use ICT in the classroom influence teachers' motivation to use ICT as a teaching.

\section{CONCLUSIONS AND RECOMMENDATIONS}

This research came to examine high school teachers' perceptions of the interactive board as a tool for teaching and learning in the Arab education system in Israel. The findings show that the public high school teachers have a positive perception of using the interactive board in teaching and learning. So, the ministry of education could build on these positive perceptions to advance the use of interactive boards in schools. Regarding the private high school teachers, the situation is different, where teachers have neutral perception of the interactive board as a tool for teaching and learning. This implies that serious efforts should be made to make the teachers there realize the benefits of the interactive board for teaching and learning, maybe the effort should start from the school administration to convince those in charge to try using the interactive boards in the classrooms, and not to be satisfied with buying just one interactive board to the school in order to feel part of the educational advancement.

The research importance lies in the fact that the implementation of interactive boards in Israel is relatively new and researches are needed to evaluate this implementation, so to act if performing some educational steps are needed. The research findings point that diverse workshops on the use of interactive board in the classroom are needed. Without these workshops, teachers will not get aware of the educational potentialities of the interactive board and will not practice utilizing these potentialities. It should be emphasized that one workshop might not be enough for the new use of the interactive board to get used to utilizing the various technological options of the interactive board. Instead general workshops and specific workshops are needed, so that the teachers know the uses of the interactive board in the various learning subjects, and at the same time know the uses of the interactive board in a specific learning subject.

\section{REFERENCES}

[1] Kent, P. (2004a). E-teaching - the elusive promise. Paper presented at the Society for Information Technology and Teacher Education International Conference 2004, Atlanta, GA, USA. Retrieved April 20, 2011 from http://education.smarttech.com/ NR/rdonlyres/B2197B4A-7164-48F8-8C79483452CB5179/0/Kent2.pdf

[2] Kent, P. (2004b). E-teaching and interactive whiteboards: Technology used to enhance effective pedagogy - creating a significant impact on classroom practice and student learning. Paper presented at the Australian Computers in Education Conference, Adelaide, 6-8 July 2004. Retrieved April 20, 2011 from; 
http://conferences.acce.edu.au/confpapers/paperdetails.asp?pid=72 $\underline{47 \& \text { docid }=106}$

[3] Cuthell, J. P. (2002). Interactive Whiteboards: new tools, new pedagogies, new learning? Retrieved April 20, 2011 from http://www.virtuallearning.org.uk/changemanage/iwb/IWB $\% 20 \mathrm{Su}$ rvey\%202004.pdf

[4] Latham, P. (2002). Teaching and learning primary mathematics: The impact of interactive whiteboards. Beam Education. Retrieved April 20, 2011 from http://www.beam.co.uk/uploads/discpdf/RES 03.pdf

[5] Levy, P. (2002). Interactive whiteboards in learning and teaching in two Sheffield schools: a developmental study. Retrieved April 20, 2011 from http://dis.shef.ac.uk/eirg/projects/wboards.htm

[6] Jones, A. \& Vincent, J. (2010). Collegial mentoring for effective whole school professional development in the use of IWB technologies. In M. Thomas \& A. Jones (Eds), Interactive whiteboards: An Australasian perspective. Australasian Journal of Educational Technology, 26(Special issue, 4), 477-493. Retrieved April 20, 2011 from http://www.ascilite.org.au/ajet/ajet26/ jones.html

[7] Campbell, C. \& Kent, P. (2010). Using interactive whiteboards in pre-service teacher education: Examples from two Australian universities. In M. Thomas \& A. Jones (Eds), Interactive whiteboards: An Australasian perspective. Australasian Journal of Educational Technology, 26 (4), 447-463. Retrieved April 20, 2011 from http://www.ascilite.org.au/ajet/ajet26/campbell.html

[8] Glover D. \& Miller D. (2001). Running with technology: the pedagogic impact of the large scale introduction of interactive whiteboards in one secondary school. Journal of Information Technology for Teacher Education, 10, 257-276. http://dx.doi.org/ $\underline{10.1080 / 14759390100200115}$

[9] Kuzminsky, T. V. (2008). Interactive Whiteboard Technology within the Kindergarten Visual Arts Classroom. A Thesis Submitted in Partial Fulfillment of the Requirements for the Degree of Master of Art Education. Georgia Public University. Retrieved April 20, 2011 from http://etd.gsu.edu/theses/available/etd-041220 08-104815/unrestricted/kuzminsky tracy_v_200805_maed.pdf.pd $\mathrm{f}$

[10] Schmid, E.C. (2008). Potential pedagogical benefits and drawbacks of multimedia use in the English language classroom equipped with interactive whiteboard technology. Computers \& Education, 51 (4), 1553-1568. http://dx.doi.org/10.1016/j.compe du.2008.02.005

[11] Wall, K., Higgins, S. and Smith, H (2005). The visual helps me understand the complicated things: pupil views of teaching and learning with interactive whiteboards. British Journal of Educational Technology 36 (5), 851-867. Retrieved April 20, 2011 from http://davidlongman.com/documents/Interactive $\% 20 \mathrm{Wh}$ iteboards/thevisualhelpsmeunderstand.pdf

[12] Beeland, W.D. Jr (2002). Student engagement, visual learning and technology: can interactive whiteboards help? Annual Conference of the Association of Information Technology for Teaching Education, Trinity College, Dublin.

[13] Lewin, C., Somekh, B., Steadman, S. (2008). Embedding interactive whiteboards in teaching and learning: The process of change in pedagogic practice. Education and Information Technologies 13 (4), 291-303. http://dx.doi.org/10.1007/s10639-008-9070-z

[14] Missika, A. \& Rotem, A. (2008). Interactive White Board: review, evaluation of its use \& uses. Online Journal (In Hebrew).

[15] Andrews, P. (2007, September). Conditions for learning: A footnote on pedagogy and didactics. Mathematics Teaching, 204, 22.

[16] Shulman, L. S. (1987). Knowledge and Teaching: Foundations for the new reform. Harvard Educational Review, 57 (1), 1-22.

[17] Shulman, L. (1986). Those who understand: Knowledge growth in teaching. Educational Researcher, 15 (2), 4-14.

[18] Jetton, T. L., \& Alexander, P.A. (1997). Instructional importance: What teachers value and what students learn. Reading Research Quarterly, 32, 290-308. http://dx.doi.org/10.1598/RRQ.32.3.4

[19] Silva, E. (2001). Pedagogic Competency of the Brazilian University Professor. Retrieved April 20, 2011 from http://www.aare. edu.au/01pap/sil01089.htm
[20] Chick, H., Baker, M., Pham, T. \& Cheng, H. (2006). Aspects of teachers' pedagogical content knowledge for decimals. In J. Novotna, H. Moraova, M. Kratka \& N. Stehlikova (Eds.), Proceedings of the $30^{\text {th }}$ conference of the International Group for the Psychology of Mathematics Education, 2, 297-304. Prague: PME.

[21] Can, G. \& Cagiltay; K. (2006). Turkish Prospective Teachers' Perceptions Regarding the Use of Computer Games with Educational Features. Educational Technology \& Society, 9 (1), 308321.

[22] Trouilloud, D.O.; Sarrazin, P.G.; Martinek T.J. \& Guillet, E. (2002). The influence of teacher expectations on students achievement in physical education classes: Pygmalion revisited, European Journal of Social Psychology, 32, 591-607. http://dx.doi.org/10.1002/ejsp.109

[23] Bar-Al, S. \& Noymeyer, M. (1996). Mipgashim em hapsikhology / Meetings with phsychology. Rekhs publishing (In Hebrew).

[24] Lee, V., Dedrick, R. \& Smith, J. (1991). The effect of the social organization of schools on teachers' efficacy and satisfaction. Sociology of Education, 64, 190-208. http://dx.doi.org/10.23 $\underline{07 / 2112851}$

[25] Selfe, C. L., \& Hawisher G. E. (2004). Literate lives in the information age: Narratives on literacy from the United Publics. Mahwah, NJ: Erlbaum.

[26] Mantero, M., \& McVicker, P. (2006). The Impact of Experience and Coursework: Perceptions of Second Language Learners in the Mainstream Classroom. Radical Pedagogy, 8(1). Retrieved April 20, 2011 from http://radicalpedagogy.icaap.org/content/issue8 1/ mantero.html

[27] Doyle, E., Stamouli, I., \& Huggard, M. (2005). Computer anxiety, self-efficacy, computer experience: An investigation throughout a computer science degree. A paper presented at the 35th Annual SEE/IEEE Frontiers in Education Conference, Indianapolis, India.

[28] Al-Dayel, S. (2005). The influence of using the computer in teaching mathematics on the achievement of grade 2 students. The Journal of Educational and Psychological Sciences, 6 (3), 49-61 (In Arabic).

[29] Al-Siyaty, A. (2004). The influence of using the computer on developing part of the innovative thinking of grade 2 students in Siwodi schools. The Journal of Educational and Psychological Sciences, 5(3), 151-177 (In Arabic).

[30] Cross, D. I. (2009). Alignment, cohesion, and change: Examining mathematics teachers' belief structures and their influence on instructional practices. Journal of Math Teacher Education, 12, 335346. http://dx.doi.org/10.1007/s10857-009-9120-5

[31] Jaber. O. \& Daher, W. (2010). Relations among the Educational Constructs of Elementary School Geometry Teachers. The International Journal of Learning, 17 (2), 371-390.

[32] [32] Jensen, G. F. (1986). Explaining differences in academic behavior between public-school and catholic-school students: A quantitative case study. Sociology of Education, 59(1), 32-41.

[33] [33] Jacob, W. J.; Holsinger, D. B.; \& Mugimu, C. B. (2008). Private secondary education in Uganda: implications for planning. Teachers College Record, 110 (4), 867-93.

[34] Lockheed, M. E. \& Zhao, Q. (1993). The empty opportunity: local control and secondary school achievement in the Philippines. International Journal of Educational Development, 13 (1), 45-62.

[35] Beasley, W. \& Sutton, R. (1993). Integration of computers in schools: Three levels of teacher expertise. Journal on Computing in Teacher Education, 9(4), 11-15.

[36] Cogill, J. (2002). How is the interactive whiteboard being used in the primary school and how does this affect teachers and teaching? Retrieved April 20, 2011 from http://www.virtuallearning.org. uk/wp-content/uploads/2010/10/IFS Interactive whiteboards in t he primary school.pdf

[37] Lai, H.-J. (2010). Secondary school teachers' perceptions of interactive whiteboard training workshops: A case study from Taiwan. In M. Thomas \& A. Jones (Eds), Interactive whiteboards: An Australasian perspective. Australasian Journal of Educational Technology, 26( 4), 511-522. Retrieved April 20, 2011 from http://www.ascilite.org.au/ajet/ajet26/lai.html

[38] Bingimlas, K. A. (2009). Barriers to the successful integration of ICT in teaching and learning environments: A review of the literature. Eurasia Journal of Mathematics, Science and Technology 
Education, 5 (3), 235-245. G. Eason, B. Noble, and I. N. Sneddon, "On certain integrals of Lipschitz-Hankel type involving products of Bessel functions," Phil. Trans. Roy. Soc. London, vol. A247, pp. 529-551, April 1955.

[39] J. Clerk Maxwell, A Treatise on Electricity and Magnetism, $3^{\text {rd }}$ ed., vol. 2. Oxford: Clarendon, 1892, pp.68-73.

[40] I. S. Jacobs and C. P. Bean, "Fine particles, thin films and exchange anisotropy," in Magnetism, vol. III, G. T. Rado and H. Suhl, Eds. New York: Academic, 1963, pp. 271-350.

[41] K. Elissa, "Title of paper if known," unpublished.

[42] R. Nicole, "Title of paper with only first word capitalized", J. Name Stand. Abbrev., in press.

[43] Y. Yorozu, M. Hirano, K. Oka, and Y. Tagawa, "Electron spectroscopy studies on magneto-optical media and plastic substrate interface," IEEE Transl. J. Magn. Japan, vol. 2, pp. 740-741, August 1987 [Digests $9^{\text {th }}$ Annual Conf. Magnetics Japan, p. 301, 1982].

[44] M. Young, The Technical Writer's Handbook. Mill Valley, CA: University Science, 1989.

\section{AUTHORS}

W. Daher is with Al-Qasemi Academic College of Education, Baka, Israel and with the College of Educational Sciences, An-Najah National University, Nablus, Palestine.

J. Abu-Hussein is with Al-Qasemi Academic College of Education, Baka, Israel

E. Alfahel is with Al-Qasemi Academic College of Education, Baka, Israel and with Kaye Academic College of Education, Beer-Sheva, Israel

Manuscript received 01 August 2011. Published as resubmitted by the authors 28 February 2012.

\section{APPENDIX}

A questionnaire that examines teachers' perceptions of the interactive board for teaching and learning in schools

Dear teacher,

Below is a questionnaire that aims to examine what teachers think about the interactive boards as a tool in the classroom.

It is important for us to know what actually you think and feel about the interactive boards.

Please read carefully the different items of the questionnaire and indicate how much you agree or disagree with the statement in each item. Thank you for your cooperation.

\section{Part I}

\section{Personal details:}
a. Gender:
1. Male
2. Female
b. My school is:
1. Public
2. Private

c. Have you participated in an interactive board training workshop? 1. Yes 2. No

d. We have interactive boards at school.

1. Yes 2. No

If answered d with 'Yes' please answer e.

e. Do you use the interactive board in your teahing? $\begin{array}{ll}\text { 1. Yes 2. No } & 0\end{array}$ f.

If you answered 'Yes' go to part II, otherwise go to item

f. What are the reasons that you do not use the interactive board in your teaching?

There are no interactive boards in my classrooms.

I do not have the required skills to use the interactive board.

The regular board is more effective than the interactive board when delivering my lessons.

Preparing lesson plans appropriate for the interactive board needs more time than preparing lesson plans appropriate for the regular board.

The working area in the interactive board is smaller than this in the regular board.

\section{Part II}

Please read carefully the following statements and indicate your agreement or disagreement with it on a scale that has four levels:
1. I strongly disagree
2. I disagree
3 I agree
4. I strongly agree

\begin{tabular}{|c|c|c|c|c|c|}
\hline & statement & \multicolumn{4}{|c|}{$\begin{array}{l}\text { Extent of your } \\
\text { agreement or } \\
\text { disagreement }\end{array}$} \\
\hline & \multicolumn{5}{|c|}{ The pedagogic aspect } \\
\hline 1. & $\begin{array}{l}\text { The interactive board assists } \\
\text { the teacher in attracting the } \\
\text { attention of the students }\end{array}$ & 1 & 2 & 3 & 4 \\
\hline 2. & $\begin{array}{l}\text { The interactive board does } \\
\text { not assist the teacher in } \\
\text { making the students pay } \\
\text { attention to the learned topic }\end{array}$ & 1 & 2 & 3 & 4 \\
\hline 3. & $\begin{array}{l}\text { The interactive board does } \\
\text { not improve the students' } \\
\text { alertness }\end{array}$ & 1 & 2 & 3 & 4 \\
\hline 4. & $\begin{array}{l}\text { The interactive board en- } \\
\text { ables the teacher to teach } \\
\text { students of different ages at } \\
\text { the same lesson }\end{array}$ & 1 & 2 & 3 & 4 \\
\hline 5. & $\begin{array}{l}\text { The interactive board en- } \\
\text { ables online learning effi- } \\
\text { ciently }\end{array}$ & 1 & 2 & 3 & 4 \\
\hline 6. & $\begin{array}{l}\text { The interactive board make } \\
\text { students with motor difficul- } \\
\text { ties enjoy their learning }\end{array}$ & 1 & 2 & 3 & 4 \\
\hline 7. & $\begin{array}{l}\text { The interactive board en- } \\
\text { courages the students to be } \\
\text { more active }\end{array}$ & 1 & 2 & 3 & 4 \\
\hline 8. & $\begin{array}{l}\text { The interactive board makes } \\
\text { students with visual and } \\
\text { concentration disabilities } \\
\text { enjoy their learning }\end{array}$ & 1 & 2 & 3 & 4 \\
\hline 9. & $\begin{array}{l}\text { The interactive board makes } \\
\text { students with reading diffi- }\end{array}$ & 1 & 2 & 3 & 4 \\
\hline
\end{tabular}



IN THE ARAB EDUCATION SYSTEM IN ISRAEL

\begin{tabular}{|c|c|c|c|c|c|}
\hline & culties enjoy their learning & & & & \\
\hline 10. & $\begin{array}{l}\text { The interactive board can } \\
\text { totally substitute the ordi- } \\
\text { nary board }\end{array}$ & 1 & 2 & 3 & 4 \\
\hline 11. & $\begin{array}{l}\text { The interactive board does } \\
\text { not assist in preparing } \\
\text { challenging activities for } \\
\text { students }\end{array}$ & 1 & 2 & 3 & 4 \\
\hline 12. & $\begin{array}{l}\text { The interactive board stimu- } \\
\text { lates students' motivation }\end{array}$ & 1 & 2 & 3 & 4 \\
\hline 13 , & $\begin{array}{l}\text { The interactive board does } \\
\text { not improve the communi- } \\
\text { cation channels of teachers } \\
\text { with their students }\end{array}$ & 1 & 2 & 3 & 4 \\
\hline 14. & $\begin{array}{l}\text { The interactive board com- } \\
\text { plement but does not substi- } \\
\text { tute the regular board }\end{array}$ & 1 & 2 & 3 & 4 \\
\hline 15. & $\begin{array}{l}\text { The interactive board en- } \\
\text { ables the students to evalu- } \\
\text { ate their learning }\end{array}$ & 1 & 2 & 3 & 4 \\
\hline 16. & $\begin{array}{l}\text { The interactive board en- } \\
\text { courages collaboration } \\
\text { among students }\end{array}$ & 1 & 2 & 3 & 4 \\
\hline & \multicolumn{5}{|c|}{ The didactic aspect } \\
\hline 17. & $\begin{array}{l}\text { The interactive board assists } \\
\text { the different learning styles } \\
\text { of students }\end{array}$ & 1 & 2 & 3 & 4 \\
\hline 18. & $\begin{array}{l}\text { The interactive board does } \\
\text { not enable the students to } \\
\text { participate in the classroom } \\
\text { discussions. }\end{array}$ & 1 & 2 & 3 & 4 \\
\hline 19. & $\begin{array}{l}\text { The interactive board sup- } \\
\text { ports a variety of teaching } \\
\text { styles }\end{array}$ & 1 & 2 & 3 & 4 \\
\hline 20 & $\begin{array}{l}\text { The interactive board en- } \\
\text { ables students to present } \\
\text { visually their ideas, ques- } \\
\text { tions and suggestions. }\end{array}$ & 1 & 2 & 3 & 4 \\
\hline 21. & $\begin{array}{l}\text { The interactive board en- } \\
\text { courages the students to be } \\
\text { highly involved in the } \\
\text { learning processes }\end{array}$ & 1 & 2 & 3 & 4 \\
\hline 22. & $\begin{array}{l}\text { The interactive board lets } \\
\text { students have more deep } \\
\text { understanding of the learn- } \\
\text { ing material }\end{array}$ & 1 & 2 & 3 & 4 \\
\hline 23. & $\begin{array}{c}\text { The interactive board assists } \\
\text { the teacher in improving his } \\
\text { teaching methods }\end{array}$ & 1 & 2 & 3 & 4 \\
\hline
\end{tabular}

\begin{tabular}{|c|c|c|c|c|c|}
\hline 24. & $\begin{array}{c}\text { The interactive board } \\
\text { changes the way teachers } \\
\text { prepare their lessons }\end{array}$ & 1 & 2 & 3 & 4 \\
\hline 25. & $\begin{array}{l}\text { The interactive board allows } \\
\text { teachers to spend less time } \\
\text { in preparing lessons }\end{array}$ & 1 & 2 & 3 & 4 \\
\hline 26. & $\begin{array}{l}\text { The interactive board en- } \\
\text { ables the teacher to vary his } \\
\text { evaluation methods }\end{array}$ & 1 & 2 & 3 & 4 \\
\hline 27. & $\begin{array}{l}\text { The interactive board does } \\
\text { not enable the students to } \\
\text { manage their own learning }\end{array}$ & 1 & 2 & 3 & 4 \\
\hline & \multicolumn{5}{|c|}{ The technical-pedagogic aspect } \\
\hline 28. & $\begin{array}{l}\text { The interactive board en- } \\
\text { courages collaboration } \\
\text { among teachers }\end{array}$ & 1 & 2 & 3 & 4 \\
\hline 29. & $\begin{array}{l}\text { The interactive board en- } \\
\text { ables the teacher to present } \\
\text { resources from the internet } \\
\text { during lesson time }\end{array}$ & 1 & 2 & 3 & 4 \\
\hline 30. & $\begin{array}{l}\text { The interactive board does } \\
\text { not allow the students to } \\
\text { enjoy their learning }\end{array}$ & 1 & 2 & 3 & 4 \\
\hline 31. & $\begin{array}{c}\text { The interactive board facili- } \\
\text { tates quick search of infor- } \\
\text { mation from the internet } \\
\text { during lesson time }\end{array}$ & 1 & 2 & 3 & 4 \\
\hline 31. & $\begin{array}{l}\text { The interactive board pre- } \\
\text { sents information more } \\
\text { clearly than the regular } \\
\text { board }\end{array}$ & 1 & 2 & 3 & 4 \\
\hline \multirow[t]{2}{*}{33.} & $\begin{array}{c}\text { The interactive board pro- } \\
\text { vides students with a variety } \\
\text { of lesson. }\end{array}$ & 1 & 2 & 3 & 4 \\
\hline & \multicolumn{5}{|c|}{ The technical-didactic aspect } \\
\hline 34. & $\begin{array}{l}\text { The interactive board en- } \\
\text { ables the teacher to carry out } \\
\text { different actions that suit his } \\
\text { teaching needs }\end{array}$ & 1 & 2 & 3 & 4 \\
\hline 35. & $\begin{array}{c}\text { The interactive board facili- } \\
\text { tates connecting with di- } \\
\text { verse software while teach- } \\
\text { ing }\end{array}$ & 1 & 2 & 3 & 4 \\
\hline 36. & $\begin{array}{l}\text { The interactive board does } \\
\text { not provide a variety of } \\
\text { technological options for } \\
\text { teaching }\end{array}$ & 1 & 2 & 3 & 4 \\
\hline
\end{tabular}

